\section{Nauplius}

The Journal OF The Brazilian Crustacean Society

e-ISSN 2358-2936

www.scielo.br/nau www.crustacea.org.br

\title{
Two new records of terrestrial isopods (Isopoda, Oniscidea) from the state of Paraíba, Brazil
}

Ivanklin Soares Campos-Filho' (D) orcid.org/0000-0001-6139-8241

Iluliane Maria Gadelha Correia ${ }^{2}$ (D) orcid.org/0000-0002-9751-1901

Emanuel da Costa Cavalcante ${ }^{2}$ (D) orcid.org/0000-0003-3015-4847

Ailson de Lima Marques² (D) orcid.org/0000-0002-6838-275X

Débora Coelho Moura² (D) orcid.org/0000-0003-2663-2308

José Otávio Aguiar ${ }^{1}$ orcid.org/0000-0003-0489-3670

\footnotetext{
${ }^{1}$ Universidade Federal de Campina Grande, Programa de Pós-Graduação em Recursos Naturais. Av. Aprígio Veloso, 882, Bairro Universitário. 58429-140 Campina Grande, Paraíba, Brazil. ISC-F E-mail: ivanklin.filho@gmail.com JOA E-mail: otavio.j.aguiar@gmail.com

${ }^{2}$ Universidade Federal de Campina Grande, Unidade Acadêmica de Geografia. Av. Aprígio Veloso, 882, Bairro Universitário. 58429-140 Campina Grande, Paraíba, Brazil. IMGC E-mail: iluli.correia@gmail.com ECC E-mail: emanueltfc@gmail.com ALM E-mail: marques.ailsonl@gmail.com DCM E-mail: debygeo@hotmail.com
}

ZOOBANK: http://zoobank.org/urn:lsid:zoobank.org:pub:71B59D66-0065-40E0942B-5E4AC73AF2C8

\section{ABstRact}

Two species of Oniscidea are recorded for the state of Paraíba for the first time. Cubaris murina Brandt, 1833 from Campina Grande and Cabaceiras and Porcellionides pruinosus (Brandt, 1833) from Campina Grande. Moreover, Alloniscus buckupi Campos-Filho \& Cardoso, 2018 and Atlantoscia floridana (Van Name, 1940) have their distribution extended, and a short discussion about the record of $A$. buckupi in a semiarid area is provided.

\section{KEYWORDS}

Woodlice, Northeastern Brazil, Caatinga biome, Neotropics, distribution.

CORRESPONDING AUTHOR Ivanklin Soares Campos-Filho ivanklin.filho@gmail.com

SUBMITTED 21 October 2019 ACCEPTED 10 January 2020 PUBLISHED 09 March 2020

DOI 10.1590/2358-2936e2020006

All content of the journal, except where identified, is licensed under a Creative Commons attribution-type BY.

Nauplius, 28: e2020006

\section{INTRODUCTION}

Terrestrial isopods (Oniscidea) comprise more than 3,800 species in 38 families distributed in almost all types of terrestrial habitats (Schmalfuss, 2003; Javidkar et al., 2015; Richardson and Araujo, 2015; Sfenthourakis 
and Taiti, 2015; Taiti, 2018). Among them, 192 species are known from Brazil, mostly from southeastern and southern regions (Campos-Filho et al., 2018a; 2019). In the state of Paraíba, Northeastern Brazil, three species are recorded, Alloniscus buckupi CamposFilho and Cardoso, 2018 (Alloniscidae) and Atlantoscia floridana (Van Name, 1940) (Philosciidae) from João Pessoa, and Armadillidium vulgare (Latreille, 1804) (Armadillidiidae) from Boqueirão (Lemos de Castro, 1985; Zimmermann et al., 2015; Campos-Filho et al., 2018b).

In this work two species of terrestrial isopods are recorded from the state of Paraíba for the first time: Cubaris murina Brandt, 1833 from Campina Grande and Cabaceiras, and Porcellionidaes pruinosus (Brandt, 1833) from Campina Grande. In addition, A. buckupi and $A$. floridana were also found to occur in Campina Grande, the former in the Caatinga biome, which will be briefly discussed below.

\section{Material and Methods}

The material was collected with the aid of pitfall traps as proposed by Aquino et al. (2006). The traps consisted of Styrofoam containers $10 \mathrm{~cm}$ high and 10 $\mathrm{cm}$ diameter with a solution of $100 \mathrm{ml}$ ethanol $70 \%$ and $5 \mathrm{ml}$ of detergent. The sampling was carried out during the dry season, from 9 to 13 October 2017. The soil salinity and $\mathrm{pH}$ levels of the sampling site were measured with aid of TDS\&EC B-M1X and ATC 0-14 pen type equipment, respectively. The material was stored in $75 \%$ ethanol and identifications were based on morphological characters. The species were examined with the aid of Biofocus SQFL-BI and Olympus $\mathrm{CH}-2$ microscopes and, when necessary, appendages were mounted in micro-preparations with Hoyer's medium (Anderson, 1954). The material is deposited in the Museu de Zoologia, Universidade de São Paulo, São Paulo, Brazil (MZUSP).

Study area

The state of Paraíba is located in northeastern Brazil with an area of about $56,000 \mathrm{~km}^{2}$ (3.6\% of the Northeastern Region total area). The state is mainly covered by Caatinga and Atlantic forest (MMA, 2015; SUDENE, 2017). The Caatinga formation has a large territorial coverage, more than $900,000 \mathrm{~km}^{2}$ (approximately 54\% of the territory of the Northeastern Region and $11 \%$ of the whole Brazilian territory), and it composes the vegetation mosaic of the Seasonal Tropical Dry forests (Andrade-Lima, 1981; Silva et al., 2011; Pereira et al., 2017; SUDENE, 2017). According to Köppen's criteria, the state has three distinct climate regions: 1) littoral, 'Agreste' and 'Brejos de Altitude' with rainfall of about 1,800 mm/year; 2) 'Sertão', with rainfall of about $820 \mathrm{~mm} /$ year; and 3) 'Borborema Plateau', with rainfall of about $800 \mathrm{~mm} /$ year (Francisco et al., 2015).

The specimens were collected in 'Campus I' of the Universidade Federal de Campina Grande (UFCG), Campina Grande, and in the municipality of Cabaceiras (Figs. 1, 2), both inserted in the Borborema Plateau and the Brazilian semiarid region (SUDENE, 2017). Campina Grande is located at $560 \mathrm{~m}$ a.s.l., annual average temperature of about $25^{\circ} \mathrm{C}$, rainfall period from February to August, and vegetation composed of Seasonal Forest and Caatinga (Limeira, 2008). Cabaceiras is located near Paraíba river, approximately $400 \mathrm{~m}$ a.s.l., with extreme Semiarid climatic domain, annual rainfall of about $270 \mathrm{~mm}$ (Corrêa et al., 2010).

\section{Systematics}

Family Alloniscidae Schimdt, 2003

\section{Genus Alloniscus Dana, 1854}

\section{Alloniscus buckupi Campos-Filho \& Cardoso, 2018}

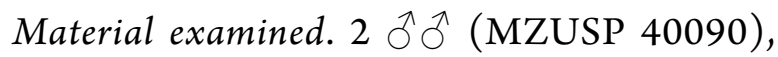
Campina Grande, Universidade Federal de Campina Grande (UFCG), 7o12'53"S 3554'54”W, 09-13 October 2017, colls. I.M.D. Correia and D.C. Moura.

Distribution. This species is recorded from Cabo Branco beach, João Pessoa (Campos-Filho et al., 2018 b). The present record considerably extends its distribution.

\section{Family Philosciidae Kinahan, 1857}

Genus Atlantoscia Ferrara and Taiti, 1981

Atlantoscia floridana (Van Name, 1940) 


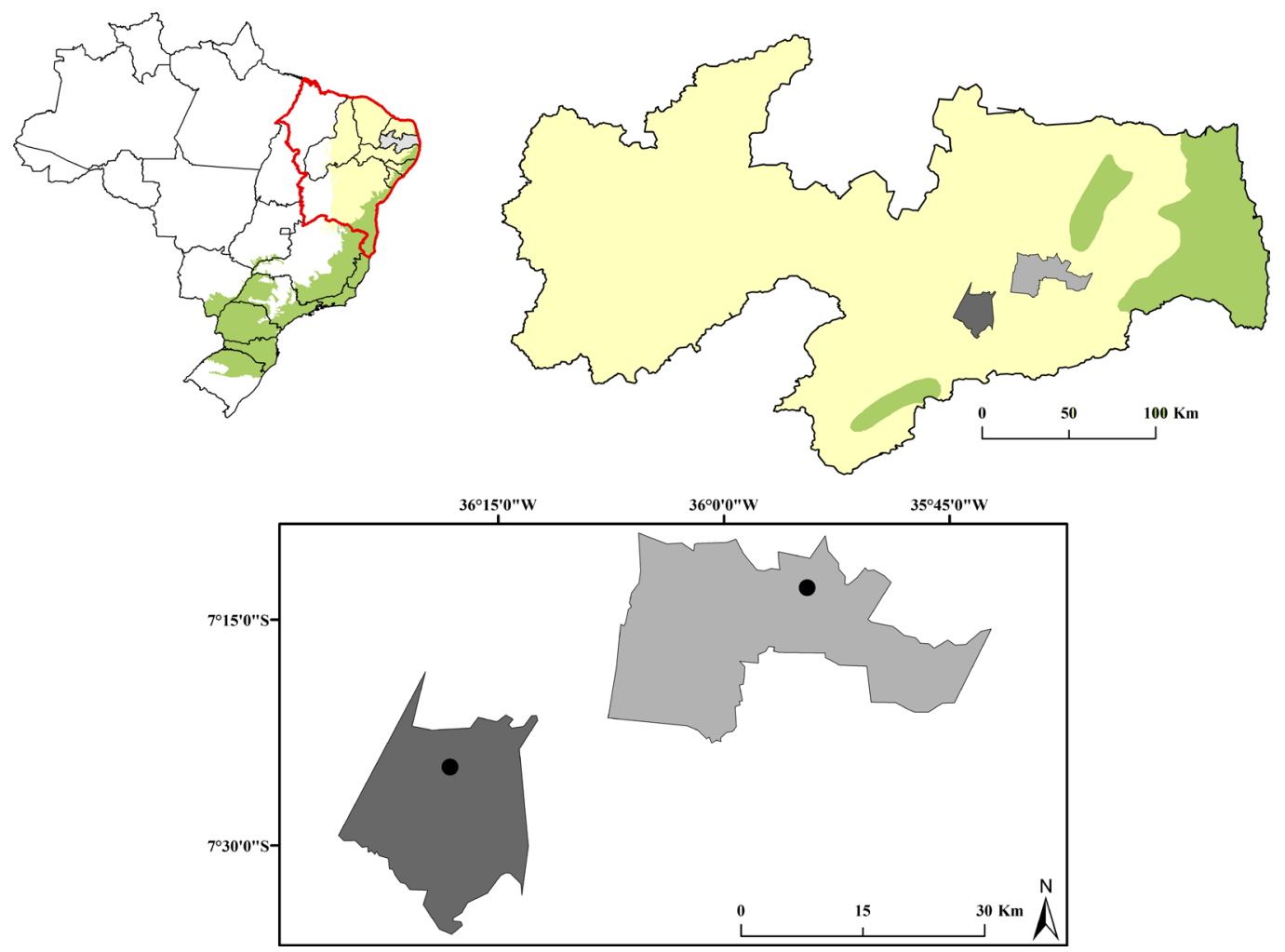

Figure 1. Sampling areas $(\bullet)$. Legend: red line $=$ Northeastern Brazil limit; yellow area $=$ Caatinga formation; green area $=$ Atlantic forest.
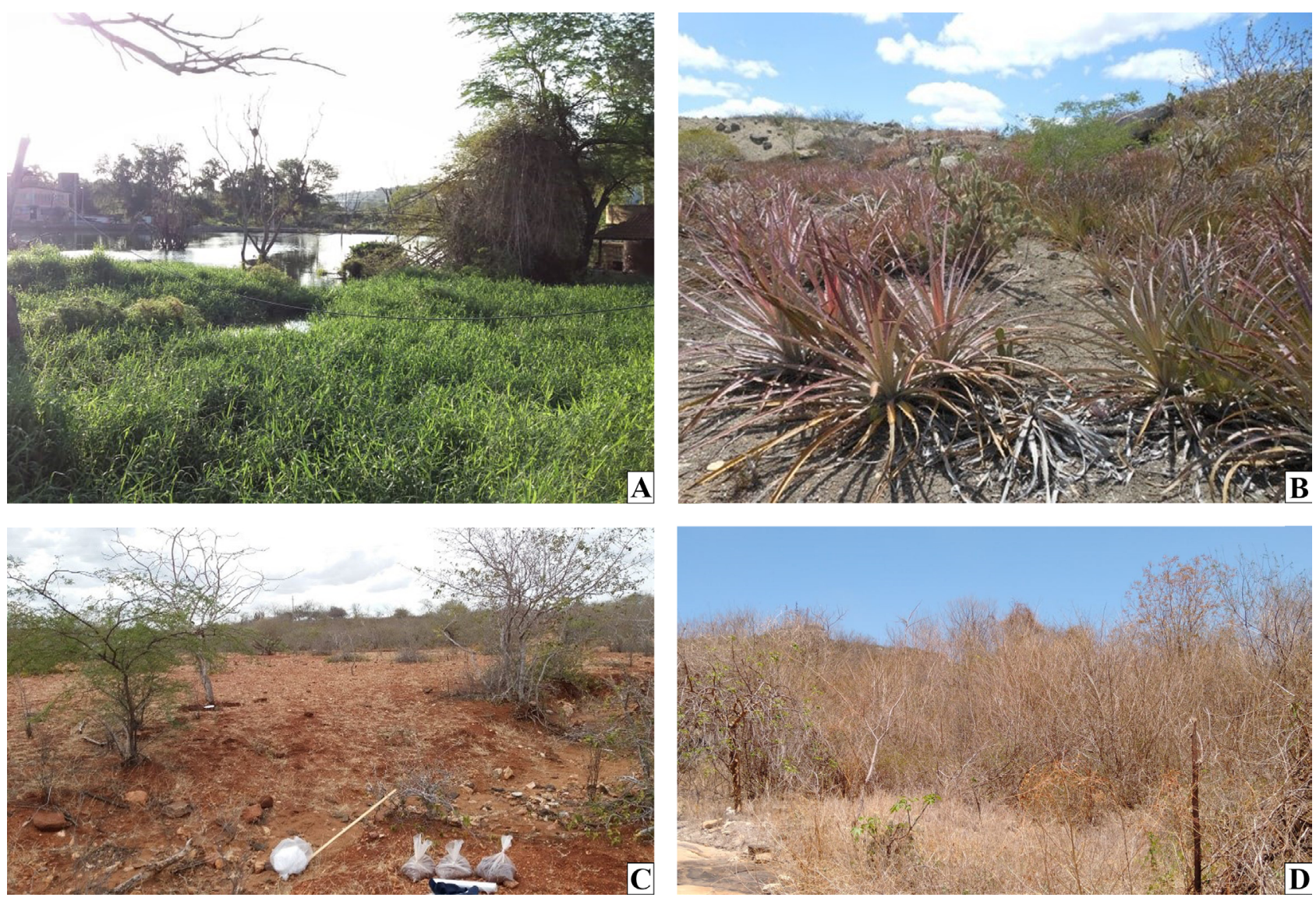

Figure 2. Study area. A, Artificial lake, Campina Grande; B, Caatinga, Campina Grande; C, D, Caatinga, Cabaceiras. 
Material examined. Many $\widehat{\partial} \widehat{\partial}$ and 99 (MZUSP 40091), Campina Grande, Universidade Federal de Campina Grande (UFCG), 7¹2'53”S 3554'54”W, 09-13 October 2017, colls. I.M.D. Correia and D.C. Moura.

Distribution. Originally described from Florida, USA (Van Name, 1940) and recorded from Argentina, Brazil (from Amapá to Rio Grande do Sul states), coastal regions of Florida, and Ascension and St. Helena Islands (Schmalfuss, 2003; Campos-Filho et al., 2013; 2018a). In the state of Paraíba, this species was recorded from Parque da Bica (Zoobotanical Garden Arruda Câmara), João Pessoa (Lemos de Castro, 1985). The present record extends the species distribution in the state.

\section{Family Armadillidae Brandt, 1833}

\section{Genus Cubaris Brandt, 1833}

\section{Cubaris murina Brandt, 1833}

Material examined. 1 त, 5 우 (MZUSP 40092), Campina Grande, Universidade Federal de Campina Grande (UFCG), 7o 12'53"S 3554'54”W, 09-13 October 2017, colls. I.M.D. Correia and D.C. Moura; 1 ก (MZUSP 40093), Cabaceiras, 7²4'46”S 3618'12”W, coll. E.M. Cavalcante.

Distribution. Circumtropical species (Schmalfuss, 2003). In Brazil, it is recorded from the states of Pará, Bahia, Mato Grosso, Mato Grosso do Sul, Espírito Santo, Paraná, and Santa Catarina (Campos-Filho et al., 2017; 2018a).

\section{Family Porcellionidae Brandt, 1831}

\section{Genus Porcellionides Miers, 1877}

\section{Porcellionides pruinosus (Brandt, 1833)}

Material examined. $4 \hat{\jmath} \widehat{\jmath}, 11$ q $ᄋ$ (MZUSP 40094), state of Paraíba, Campina Grande, Universidade Federal de Campina Grande (UFCG), 09-13 October 2017, leg. I.M.G. Correia and D.C. Moura.

Distribution. Cosmopolitan species of Mediterranean origin (Schmalfuss, 2003). In Brazil, it is recorded from the states of Bahia, Ceará, Espírito Santo, Pará, Piauí, Rio Grande do Sul, and Santa Catarina (Campos-Filho et al., 2018a).

\section{Discussion}

To date, the Caatinga comprises a high biodiversity with a high number of endemics (Leal et al., 2005; Loebmann \& Haddad, 2010), and, as other Brazilian biomes, suffers with high levels of degradation due to overexploitation of its natural resources (Alves et al., 2009).

Among the species mentioned here, the most intriguing is the presence of A. buckupi in a semiarid area. To date, all species of Alloniscus are distributed in coastal areas, except the doubtful A. simplex Schmölzer, 1974 from Aberdare mountains, Kenya (Schmalfuss, 2003; Campos-Filho et al., 2018b). The specimens of A. buckupi were collected near an artificial lake within UFCG (Fig. 1A), where the dissolved salt and $\mathrm{pH}$ levels strongly exceed sea levels (1,282 ppm and 10.8 vs. $35 \mathrm{ppm}$ and 7.4-8.5). Salt dependency related with physiology have been published in different groups of littoral species (e.g., Moens and Vincx, 2000; Braby and Somero, 2009; Pétillon et al., 2011; Sandman et al., 2013). Within Oniscidea, many papers regarding the systematics of coastal species have been published (e.g., Taiti and Howarth, 1996; Taiti et al., 2003; 2018; Taiti and Lopez, 2008; Messina et al., 2011; 2012; Lisboa el al., 2017; Pérez-Schultheiss et al., 2018), but only a few studies approached the relationships between species and salt environments (e.g., Barnes, 1932; 1934; 1935; 1940; Zimmer et al., 2002; Lopes-Leitzke et al., 2009; 2011). Alloniscus buckupi is considered to be introduced to Campina Grande and, probably, the salt levels of the artificial lake allow the species to survive in this area. All species of the genus are diggers on sandy beaches, probably to avoid water loss and predation (see Schmalfuss, 1884). Campos-Filho et al. (2018b) mentioned that specimens of $A$. buckupi were collected during a drizzle in Cabo Branco beach, João Pessoa. The specimens from Campina Grande were collected from soil samples, confirming the digger habit of this species. 


\section{ACKNOWLEDGMENTS}

This study was partially funded by CAPES (Coordenação de Aperfeiçoamento de Pessoal de Nível Superior), Finance Code 001, and a PNPD scholarship to ISC-F (CAPES/PNPD/UFCG/ CTRN/PPGRN/201713705-5).

\section{RefERENCES}

Alves, J.J.A.; Araújo, M.A. and Nascimento, S.S. 2009. Degradação da Caatinga: uma investigação ecogeográfica. Revista Caatinga, 22: $126-135$

Anderson, L.E. 1954. Hoyer's solution as a rapid permanent mounting medium for bryophytes. The Bryologist, 57: 242.

Andrade-Lima, D.A. 1981. The caatinga dominium. Revista Brasileira de Botânica, 4: 149-153.

Aquino, A.M.; Aguiar-Menezes, E.L. and Queiroz, J.M. 2006. Recomendações para coleta de artrópodes terrestres por armadilhas de queda ("Pitfall-Traps"). Circular Técnica (EMBRAPA), 18: 1-8.

Barnes, T. 1932. Salt requirements and space orientation of the littoral isopod Ligia in Bermuda. Biological Bulletin. Marine biological Laboratory, Woods Hole, 63: 496-504.

Barnes, T. 1934. Further observations on the salt requirements of Ligia in Bermuda. Biological Bulletin. Marine biological Laboratory, Woods Hole, 66: 124-132.

Barnes, T. 1935. Salt requirements and orientation of Ligia in Bermuda. III. Biological Bulletin. Marine biological Laboratory, Woods Hole, 69: 259-268.

Barnes, T. 1940. Experiments on Ligia in Bermuda. VII. Further effects of sodium, ammonium and magnesium. Biological Bulletin. Marine biological Laboratory, Woods Hole, 78: 35-41.

Braby, C.E. and Somero, G.N. 2006. Following the heart: temperature and salinity effects on heart rate in native and invasive species of blue mussels (genus Mytilus). The Journal of Experimental Biology, 209: 2554-2566.

Brandt, J.F. 1833. Conspectus Monographiae Crustaceorum Oniscodorum Latreillii. Byulleten Moskovskogo Obshchestva Ispŷtateleı̆ Prirodŷ, 6: 171-193, pl. 4.

Campos-Filho, I.S.; Cardoso, G.M. and Aguiar, J.O. 2018 a. Catalogue of terrestrial isopods (Crustacea, Isopoda, Oniscidea) from Brazil: an update with some considerations. Nauplius, 26: e2018038.

Campos-Filho, I.S.; Cardoso, G.M. and Aguiar, J.O. 2018b. New species and first record of Alloniscus Dana, 1854 (Isopoda, Oniscidae, Alloniscidae) from Brazil. Nauplius, 26: e2018014.

Campos-Filho, I.S.; Fernandes, C.S.; Cardoso, G.M.; Bichuette, M.E.; Aguiar, J.O. and Taiti, S. 2019. Two new species and new records of terrestrial isopods (Crustacea, Isopoda, Oniscidea) from Brazilian caves. Zootaxa, 4564: 422-448.

Campos-Filho, I.S.; Lisboa, J.T. and Araujo, P.B. 2013. Review of Atlantoscia Ferrara \& Taiti, 1981 (Crustacea: Isopoda: Oniscidea: Philosciidae) with new records and new species. Organisms, Diversity \& Evolution, 13: 463-483.
Campos-Filho, I.S.; Montesanto, G.; Araujo, P.B. and Taiti, S. 2017. New species and new records of terrestrial isopods (Crustacea, Isopoda, Oniscidea) from Brazil. Iheringia, Série Zoologia, 107: e2017034.

Corrêa, A.C.B.; Tavares, B.A.C.; Monteiro, K.A.; Cavalcanti, L.C.S. and Lira, D.R. 2010. Megageomorfologia e morfoestrutura do Planalto da Borborema. Revista do Instituto Geológico, $31: 35-52$.

Dana, J.D. 1854. Catalogue and description of Crustacea collected in California by Dr. John L. Le Conte. Proceedings of the Academy of Natural Sciences of Philadelphia, 7: 175-177.

Ferrara, F. and Taiti, S. 1981. Terrestrials isopods from Ascension Island. Monitore Zoologico Italiano, 13 (Suppl. 14): 189-198.

Francisco, P.R.M.; Medeiros, R.M.; Santos, D. and Matos, R.M. 2015. Classificação Climática de Köppen e Thornthwaite para o Estado da Paraíba. Revista Brasileira de Geografia Física, 8: 1006-1016.

Javidkar, M.; Cooper, S.J.B.; King, R.A.; Humphreys, W.F. and Austin, A. 2015. Molecular phylogenetic analyses reveal a new southern hemisphere oniscidean family (Crustacea: Isopoda) with a unique water transport system. Invertebrate Systematics, 29: 554-577.

Kinahan, J. 1857. Analysis of certain allied genera of terrestrial isopods; with description of a new genus, and a detailed list of the British species of Ligia, Philougria, Philoscia, Porcellio, Oniscus and Armadillium [sic]. Natural History Review, 4: 258-282, pls. 19-22.

Latreille, P.A. 1804. Histoire naturelle, générale et particulière des Crustacés et des Insectes. p. 1-413, pls 58-66. In: C.S. Sonnini (ed), Histoire naturelle, générale et particulière, des Crustacés et Insectes: ouvrage faisant suite aux oeuvres de Leclerc de Buffon, et partie du Cours complet d'Histoire naturelle. Vol. VII. Paris, L'Imprimeria de F. Dufart.

Leal, I.R.; Silva, J.M.C.; Tabarelli, M. and Lacher Jr., T.E. 2005. Changing the course of biodiversity conservation in the Caatinga of Northeastern Brazil. Conservation Biology, 19: 701-706.

Lemos de Castro, A. 1985. Considerações sobre Atlantoscia alceui Ferrara \& Taiti, 1981 (Isopoda, Oniscoidea, Philosciidae). Revista Brasileira de Biologia, 45: 417-422.

Limeira, T.M.S. 2008. Variabilidade e Tendência das Chuvas no Estado da Paraíba. Master thesis in Meteorology, Programa de Pós-graduação em Meteorologia, Universidade Federal de Campina Grande. Campina Grande, 122p. [Unpublished].

Lisboa, J.T.; Campos-Filho, I.S.; Couto, E.C.G. and Araujo, P.B. 2017. Distribution of terrestrial isopods of the genus Littorophiloscia (Isopoda, Halophilosciidae) along the Brazilian coast. North-Western Journal of Zoology, 13: 354-356.

Loebmann, D. and Haddad, C.F.B. 2010. Amphibians and reptiles from a highly diverse area of the Caatinga domain: composition and conservation implications. Biota Neotropica, 10(3): http://www.biotaneotropica.org.br/v10n3/en/ abstract?article+bn03910032010.

Lopes-Leitzke, E.R.; Dumont, L.F.C. and D’Incao, F. 2009. Growth of Ligia exotica (Isopoda: Oniscidea: Ligiidae) in two estuarine regions of Patos Lagoon, Rio Grande do Sul, Brazil. Journal of the Marine Biological Association of the United Kingdom, 89: 735-741 
Lopes-Leitzke, E.R.; Macedo, C.W.S.S.; Longaray, D.A. and D’Incao, F. 2011. Natural diet of Ligia exotica (crustacea, isopoda, ligiidae) in two estuarine regions of Patos Lagoon, Rio Grande do Sul, Brazil. Atlântica, 33: 149-160.

Messina, G.; Montesanto, G.; Pezzino, E.; Caruso, D. and Lombardo, B.M. 2011. Diversity of terrestrial isopods in a protected area characterized by salty coastal ponds (Vendicari, Sicily). Journal of Natural History, 45: 2145-2158.

Messina, G.; Pezzino, E.; Montesanto, G.; Caruso, D. and Lombardo, B.M. 2012. The diversity of terrestrial isopods in the natural reserve "Saline di Trapani e Paceco" (Crustacea, Isopoda, Oniscidea) in northwestern Sicily. ZooKeys, 176: 215-230.

Miers, E. 1877. On a collection of Crustacea, Decapoda and Isopoda, chiefly from South America, with descriptions of new genera and species. Proceedings of the Zoological Society of London, 1877: 653-679, pls. 66-69.

MMA - Ministério do Meio Ambiente. 2015. Mapa de vegetação nativa na área de aplicação da Lei no. 11.428/2006 - Lei da Mata Atlântica (ano base 2009). Secretaria de Biodiversidade e Florestas, Brasília, 85p.

Moens, T. and Vincx, M. 2000. Temperature and salinity constraints on the life cycle of two brackish-water nematode species. Journal of Experimental Marine Biology and Ecology, 243: 115-135.

Pereira, T.M.S.; Moura, D.C.; Silva, J.A.L.; Rodrigues, E.M. and Melo, J.I.M. 2017. Resgate Florístico da Vegetação de Floresta Estacional no Município de Campina Grande - PB. Revista Geográfica Acadêmica, 11: 1-12.

Pérez-Schultheiss, J.; Ayala, K.; Fariña, J.M. and Coccia, C. 2018. Exotic oniscideans (Crustacea: Isopoda) in coastal salt marshes: first record of the families Halophilosciidae and Platyarthridae in Continental Chile. New Zealand Journal of Zoology, 46: 225-235.

Pétillon, J.; Lambeets, K.; Ract-Madoux, B.; Vernon, P. and Renault, D. 2011. Saline stress tolerance partly matches with habitat preference in ground-living wolf spiders. Physiological Entomology, 36: 165-172.

Richardson, A. and Araujo, P.B. 2015. Lifestyles of terrestrial crustaceans. p. 299-336. In: M. Thiel and L. Watling (eds), The natural history of the Crustacea. Lifestyles and feeding biology. Oxford, Oxford University Press.

Sandman, A.N.; Wikström, S.A.; Bloqvist, M.; Kautsky, H. and Isaeus, M. 2013. Scale-dependent influence of environmental variables on species distribution: a case study on five coastal benthic species in the Baltic Sea. Ecography, 36: 354-363.

Schmalfuss, H. 1984. Eco-morphological strategies in terrestrial isopods. Proceedings of the Zoological Society of London, 53: 49-63.
Schmalfuss, H. 2003. World catalog of terrestrial isopods (Isopoda: Oniscidea). Stuttgarter Beiträge zur Naturkunde, 654: 1-341.

Schmidt, C. 2003. Contribution to the phylogenetic system of the Crinocheta (Crustacea, Isopoda). Part 2 (Oniscoidea to Armadillidiidae). Mitteilungen aus dem Museum für Naturkunde in Berlin, Zoosystematics and Evolution, 79: 3-179.

Schmölzer, K. 1974. Landisopoden aus Zentral- und Ostafrika. Sitzungsberichte der österreichischen Akademie der Wissenschaften, Mathematisch-naturwissenschaftliche Klasse, Abteilung I, 182: 147-200.

Sfenthourakis, S. and Taiti, S. 2015. Patterns of taxonomic diversity among terrestrial isopods. ZooKeys, 515: 13-25.

Silva, J.M.C.; Barbosa, L.C.F.; Leal, I.R. and Tabarelli, M. 2011. The Caatinga: understanding the challenges. p. 3-21. In: J.M.C. Silva; I. Leal and M. Tabarelli (eds), Caatinga: The Largest Tropical Dry Forest Region in South America. Cham (Switzerland), Springer.

SUDENE - Superintendência do Desenvolcimento do Nordeste. 2017. Nova delimitação do Semiárido. Available at: http:// www.sudene.gov.br/images/arquivos/semiarido/arquivos/ Rela\%C3\%A7\%C3\%A3o_de_Munic\%C3\%ADpios_ Semi\%C3\%A1rido.pdf [Accessed on 10 October 2019].

Taiti, S. 2018. Biologia e biogeografia degli isopodi terrestre (Crustacea, Isopoda, Oniscidea). Atti Accademia Nazionale Italiana di Entomologia, Anno LXV: 83-90.

Taiti, S.; Arnedo, M.A.; Lew, S.E. and Roderick, G.K. 2003. Evolution of terrestrially in Hawaiian species of the genus Ligia (Isopoda, Oniscidea). Crustaceana Monographs, 2: 85-102.

Taiti, S.; Montesanto, G. and Vargas, J.A. 2018. Terrestrial Isopoda (Crustacea, Oniscidea) from the coasts of Costa Rica, with descriptions of three new species. Revista de Biología Tropical, 66 (Suppl. 1): S187-S210.

Taiti, S. and Howarth, F. 1996. Terrestrial isopods (Isopoda: Oniscidea) from the Hawaiian Islands. Occasional Papers of the Bishop Museum, 45: 59-71.

Taiti, S. and López, H. 2008. New records and species of Halophilosciidae (Crustacea, Isopoda, Oniscidea) from the Canary Islands (Spain). p. 37-52. In: Z. Zimmer; F. Charfi-Cheikhrouha and S. Taiti (eds), Proceedings of the International Symposium of Terrestrial Isopod Biology ISTIB-07. Aachen, Shaker Verlag.

Van Name, W.G. 1940. A supplement to the American land and freshwater isopod Crustacea. Bulletin of the American Museum of Natural History, 77: 109-142.

Zimmermann, B.L.; Bouchon, D.; Almerão, M.P. and Araujo, P.B. 2015. Wolbachia in Neotropical terrestrial isopods. FEMS Microbiology Ecology, 91: fiv025. 